\title{
MicroRNA 483-5p
}

National Cancer Institute

\section{Source}

National Cancer Institute. MicroRNA 483-5p. NCI Thesaurus. Code C131519.

A 22 ribonucleotide sequence that is a final product of the processing of MIR483 pre-

miRNA. This oligonucleotide may be involved in the negative regulation of gene expression. 